\title{
PENGARUH BINTANG IKLAN, KEPRIBADIAN MEREK, DAN KARAKTERISTIK PRODUK TERHADAP INTENSI MEMBELI GARNIER LIGHT COMPLETE VERSI CHELSEA ISLAN (Studi Kasus pada Mahasiswi UNJ)
}

\author{
M. Edo S. Siregar \\ Fakultas Ekonomi Universitas Negeri Jakarta \\ Email: edosiregar@unj.ac.id \\ Wafa Silmy Kaffah \\ Fakultas Ekonomi Universitas Negeri Jakarta \\ Email: wafasilmykaffah@yahoo.com \\ Ika Febrilia \\ Fakultas Ekonomi Universitas Negeri Jakarta \\ Email: $\underline{\text { ikafebrilia@unj.ac.id }}$
}

\begin{abstract}
ABSTRAK
Penelitian ini bertujuan untuk mengetahui: (1) pengaruh bintang iklan terhadap intensi membeli Garnier Light Complete, (2) pengaruh kepribadian merek terhadap intensi membeli Garnier Light Complete, (3) pengaruh karakteristik produk terhadap intensi membeli Garnier Light Complete. Populasi pada penelitian ini adalah mahasiswi UNJ yang belum pernah menggunakan produk Garnier Light Complete. Teknik pengambilan sampel dalam penelitian ini menggunakan purposivesampling dengan jumlah sampel sebanyak 200. Teknik pengumpulan datamenggunakan kuesioner yang telah diuji validitas dan reliabilitasnya. Teknik analisis data yang digunakan untuk menjawab hipotesis penelitian ini adalah uji asumsi klasik, analisis deskriptif dan analisis regresi linier berganda. Hasilpenelitian ini menunjukkan bahwa: (1) bintang iklan memiliki pengaruh yang signifikan terhadap intensi membeli,(2) kepribadian merek tidak memiliki pengaruh yang signifikan terhadap intensi membeli, (3) karakteristik produk memiliki pengaruh yang signifikan terhadap intensi membeli.
\end{abstract}

Kata Kunci: Bintang Iklan, Kepribadian Merek, Karakteristik Produk, Intensi Membeli. 


\section{PENDAHULUAN}

Dalam era globalisasi persaingan bisnis semakin marak terjadi, bukan hanya menyediakan peluang tetapi juga perusahaan akan mengalami tantangan yang beragam untuk selalu mendapatkan cara terbaik guna merebut dan mempertahankan pangsa pasar. Setiap perusahaan berusaha untuk menarik perhatian calon konsumennya dengan berbagai cara, seperti pemikiran-pemikiran yang baru yang dapat membangun produk atau jasa yang nantinya akan memberikan nilai lebih terhadap pelanggan (Nurani dan Heryanto, 2010).

Di era sekarang ini, konsumen berperilaku lebih selektif dalam melakukan pembelian, termasuk dalam memilih produk kecantikan.Saat ini konsumen mulai resah ketika melihat banyaknya kabar beredar tentang produk kecantikan yang palsu atau tidak baik untuk kulit mereka. Hal ini dikarenakan kurangnya informasi yang dimiliki, maka dari itu para konsumen membuat banyak keputusan pembelian setiap hari dan kebanyakan perusahaan besar meneliti keputusan pembelian konsumen secara rinci menjawab pertanyaan tentang apa yang dibeli konsumen, dimana mereka membeli, bagaimana dan berapa banyak yang mereka beli, kapan mereka membeli, dan mengapa mereka membeli (Kotler dan Armstrong, 2012).

Terkait dengan perilaku pembelian tersebut, dimana terdapat banyak proses sebelum konsumen melakukan keputusan pembelian, pemasar tentu ingin mengawalinya dengan menimbulkan niat beli dari konsumen. Niat beli konsumen adalah tahapan konsumen melakukan pengevaluasian terhadap informasi yang diterima, hal ini juga berarti bahwa niat beli konsumen adalah apa yang dipikirkan oleh konsumen untuk dibeli (Hartini, 2012).

Jika suatu produk ingin dikenal banyak orang harus memakai periklanan, agar semua orang tahu informasi produk tersebut dan produsen mendapat peluang untuk mendapatkan konsumen. Iklan dapat dilakukan melalui berbagai media, baik media cetak seperti koran, majalah, dan brosur ataupun media elektronik seperti televisi, radio dan internet. Salah satu media iklan yang sering dipakai adalah televisi, agar produk yang ditawarkan pemasar melalui media iklan memiliki daya tarik bagi calon konsumen untuk 
membeli, maka diperlukan dukungan tokoh terkenal ataupun artis sebagai penyampai pesan dalam iklan (Nurani dan Haryanto, 2010).

Dalam iklan, pemilihan tokoh terkenal akan sangat membantu perusahaan dalam menciptakan intensi pembelian. Seorang tokoh terkenal yang merupakan artis, aktor, dan atlet yang dikenal masyarakat karena prestasinya dan berperan sebagai orang yang berbicara tentang produk yang akan mereka promosikan, pada akhirnya dapat mempengaruhi sikap dan perilaku konsumen yang tertuju pada produk yang didukungnya. Menurut Shimp (2010:188), salah satu fungsi iklan yang paling penting adalah untuk mempublikasikan merek dan pengiklan, memanfaatkan nilai kepercayaan dengan memilih bintang iklan yang secara luas dianggap sebagai orang yang jujur dan baik, mungkin untuk dapat mempublikasikan mereknya.Menurut Shimp (2010:188), salah satu fungsi iklan yang paling penting adalah untuk mempublikasikan merek dan pengiklan, memanfaatkan nilai kepercayaan dengan memilih bintang iklan yang secara luas dianggap sebagai orang yang jujur dan baik, mungkin untuk dapat mempublikasikan mereknya.

Melihat fenomena banyaknya iklan di televisi, produk maupun jasa yang menggunakan tokoh terkenal sebagai bintang iklan, salah satunya adalah Garnier Indonesia yang merupakan industri kecantikan selama lebih dari 110 tahun, memberdayakan bahan-bahan alami, ilmu pengetahuan dan teknologi untuk menjawab masalah dan aspirasi wanita Indonesia.Garnier pada tahun 2015 meluncurkan produk perawatan kulit terbaru dengan formula yang lebih baik dari sebelumnya untuk iklim dan kulit orang Indonesia, yaitu NEW Garnier Light Complete. Dengan NEW Garnier Light Complete, wanita Indonesia bisa mengucapkan selamat tinggal kepada masalah kulit wajah kusam, dan mereka juga dapat memenuhi aspirasi mereka untuk mendapatkan kulit putih bercahaya. Sebagai bentuk komitmennya untuk membuat wanita Indonesia percaya diri melalui kecantikan mereka, Garnier melakukan studi perilaku konsumen (http://www.loreal.co.id).

Penelitian ini mencoba memahami masalah dan aspirasi wanita Indonesia, sehingga dapat melihat cara mereka ingin dilihat, mereka dapat percaya diri dan bercahaya dari dalam. Menurut Reny K. Agustina, selaku Garnier Marketing Manager, PT. L'Oreal Indonesia "Penelitian terbaru yang dilakukan oleh Garnier telah menunjukkan bahwa wanita Indonesia masih merasa bahwa kulit kusam adalah masalah utama yang mereka 
alami, dan kemudian diikuti oleh kulit berminyak dan noda gelap pada wajah mereka. Wanita Indonesia juga ingin memiliki kulit putih dan bersih bercahaya dan tahan lama". Garnier juga mengumumkan bintang iklan terbarunya yaitu, seseorang yang menjunjung tinggi nilai-nilai Garnier, dia adalah bintang bersinar pendatang baru dengan potensi yang sangat besar dalam industri hiburan di Indonesia, yaitu Chelsea Islan (http://www.loreal.co.id).

Menurut Shimp (2010:459), bintang iklan adalah pendukung suatu produk. Bintang iklan adalah penggunaan tokoh terkenal sebagai pendukung suatu produk di media-media, mulai dari media cetak, media sosial, maupun media televisi (Shimp, 2010:460). Bintang iklan juga diartikan sebagai sosok orang yang dipercaya mampu menyampaikan pesan tentang produk terkait kepada calon konsumen.

Menurut Kotler dan Keller (2012), sebuah kepribadian merek dapat membantu proses komunikasi pada konsumen dikarenakan memberi kemudahan pada konsumen untuk mengidentifikasi merek. Dari pengertian para ahli tersebut, dapat disimpulkan bahwa kepribadian merek adalah sebuah karakter yang dimiliki oleh merek guna membedakan merek dengan pesaingnya dan membantu konsumen untuk mengidentifikasi merek. Kepribadian merek pada Garnier Light Complete ini sendiri adalah sebagai produk perawatan kulit wajah yang memberdayakan bahan-bahan alami yang diharapkan dapat mempengaruhi intensi membeli konsumen.

Menurut Kotler (2012), karakteristik produk adalah perusahaan menampilkan ciriciri khusus atau spesifik dari produk tersebut agar berbeda di pasar, sehingga konsumen dapat dengan mudah membedakan suatu produk dengan produk lain yang ada di pasaran, seperti Garnier sendiri yang memiliki ciri khusus yaitu produk perawatan kulit bernuansa warna kuning yang menandakan ciri khas dari rangkaian produk Garnier Light Complete dan juga aroma buah lemon yang menyegarkan.

Perusahaan berharap dengan memberikan informasi kepada calon konsumen tentang kepribadian merek dan karakteristik produk melalui media iklan yang didukung oleh bintang iklan yang dikenal baik oleh masyarakat luas, dapat mempengaruhi intensitas pembelian terhadap produk yang ditawarkan. Apakah dengan peringkat 2 TOP BRAND yang didapat Garnier Light Complete pada tahun 2015 hingga tahun 2017 tersebut, disebabkan oleh pengaruh bintang iklan yang Garnier pilih, kepribaadian merek, dan juga 
karakteristik produk yang ada pada Garnier Light Complete itu sendiri. Oleh sebab itu, peneliti tertarik untuk melakukan sebuah penelitian yang berjudul "Pengaruh Bintang Iklan, Kepribadian Merek dan Karakteristik Produk terhadap Intensi Membeli Garnier Light Complete versi Chelsea Islan (Studi Kasus pada Mahasiswi UNJ)”.

\section{Rumusan Masalah}

Berdasarkan latar belakang masalah yang telah diuraikan sebelumnya, maka dapat dirumuskan empat persoalan penelitian sebagai berikut:

1. Apakah bintang iklan berpengaruh terhadap intensi membeli Garnier Light Complete versi Chelsea Islan?

2. Apakah kepribadian merek berpengaruh terhadap intensi membeli Garnier Light Complete versi Chelsea Islan?

3. Apakah karakteristik produk berpengaruh terhadap intensi membeli Garnier Light Complete versi Chelsea Islan?

\section{Tujuan Penelitian}

Tujuan penelitian merupakan jawaban atau saran yang ingin dicapai penulis dalam sebuah penelitian. Oleh sebab itu, tujuan penelitian ini adalah:

1. Untuk mengetahui pengaruh bintang iklan terhadap intensi membeli Garnier Light Complete versi Chelsea Islan.

2. Untuk mengetahui pengaruh kepribadian merek terhadap intensi membeli Garnier Light Complete versi Chelsea Islan.

3. Untuk mengetahui pengaruh karakteristik produk terhadap intensi membeli Garnier Light Complete versi Chelsea Islan.

\section{TELAAH PUSTAKA}

Menurut Anoraga (2010), intensi membeli atau niat beli merupakan suatu proses pengambilan keputusan yang dilakukan oleh konsumen sebelum mengadakan pembelian atas produk yang ditawarkan atau yang dibutuhkan oleh konsumen tersebut. Menurut Assael (2011), intensi membeli adalah kecenderungan konsumen untuk membeli suatu merek atau mengambil tindakan yang berhubungan dengan pembelian yang diukur dengan tingkat kemungkinan konsumen melakukan pembelian. 
Menurut Sumarwan (2012:258), pembelian produk dan jasa serta pemilihan merek, para tokoh terkenal bisa memiliki pengaruh kuat kepada konsumen. Para tokoh terkenal memiliki inner beauty, kharisma dan kredibilitas. Bintang iklan menurut Shimp (2010:459), "bintang iklan adalah pendukung iklan atau seseorang yang bekerja untuk mendukung suatu produk”. Menurut Shimp (2010:251), lima atribut khusus bintang iklan dijelaskan dengan akronim TEARS yang meliputi:trustworthiness (dapat dipercaya), expertise (memiliki keahlian), attractiveness (memiliki daya tarik fisik), respect (memiliki rasa menghormati), dan similarity (kesamaan dengan audience yang dituju).

Kepribadian merek didefinisikan sebagai seperangkat karakteristik manusia yang berhubungan dengan merek (Aaker, 2010). Merek dengan kepribadian cenderung lebih mengesankan dan lebih baik dibandingkan dengan merek yang tanpa karakteristik, sama seperti manusia, merek dapat memiliki berbagai kepribadian seperti menjadi profesional ataupun menjadi kompeten (Aaker, 2010). Kepribadian merek dapat digunakan sebagai salah satu cara untuk membedakan merek terhadap pesaingnya (Aaker, 2010). Kotler dan Keller (2012), mendefinisikan kepribadian merek sebagai "the specific mix19 of human traits that we canattribute to a particular brand", yang berarti kumpulan spesifik dari sifat manusia yang dapat kita artikan kepada sebuah merek tertentu.

Karakteristik produk adalah ciri-ciri khusus atau spesifik dari produk yang berbeda dari pesaing dan dapat ditawarkan ke pasar untuk memenuhi keinginan atau kebutuhan pelanggan (Kotler dan Keller, 2012). Karakteristik produk sendiri dapat terdiri dari warna, kemasan, ukuran, manfaat dan inovasi (Solomon, 2010).Dalam membeli suatu produk, konsumen akan mengarahkan pada fungsi dan manfaatnya (Kotler dan Keller, 2012). 


\section{MODEL PENELITIAN}

Uraian dari seluruh variabel yang diangkat dalam penelitian ini, maka dapat dibuat kerangka model penelitian seperti gambar berikut:

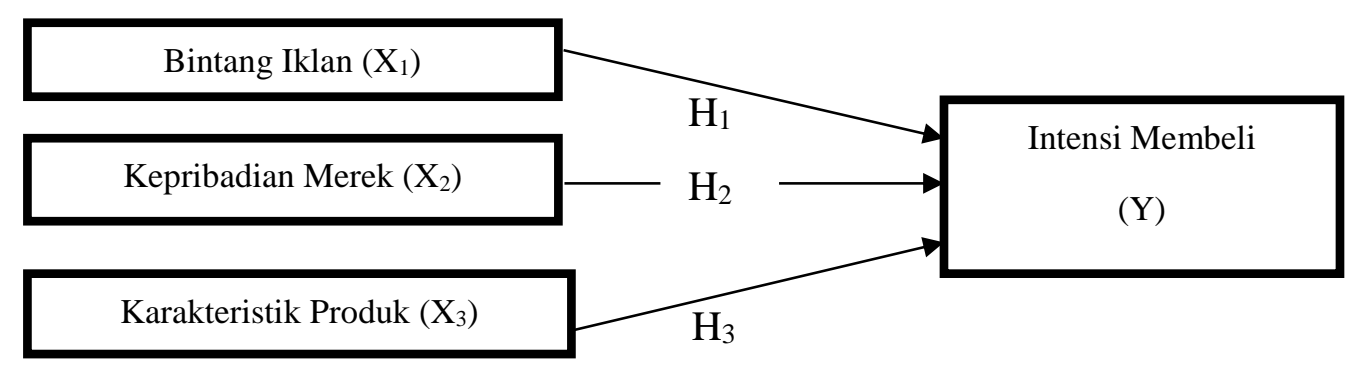

Gambar 1. Kerangka Penelitian

Sumber: Data diolah oleh peneliti (2017)

\section{Perumusan Hipotesis Penelitian}

Hipotesis disusun berdasarkan teori dan kerangka berpikir yang sudah diuraikan sebelumnya, maka dari teori dan kerangka berpikirdapatdisusun beberapa hipotesis sebagai berikut:

1. $\mathrm{H}_{1}$ : Terdapat pengaruh bintang iklan terhadap intensi membeli Garnier Light Complete versi Chelsea Islan.

2. $\mathrm{H}_{2}$ : Terdapat pengaruh kepribadian merek terhadap intensi membeli Garnier Light Complete versi Chelsea Islan.

3. $\mathrm{H}_{3}$ : Terdapat pengaruh karakteristik produk terhadap intensi membeli Garnier Light Complete versi Chelsea Islan.

\section{HASIL DAN PEMBAHASAN}

Karakteristik Responden

\section{Umur}

Tabel 1. Karakteristik Responden Berdasarkan Umur

\begin{tabular}{ccc}
\hline Umur & Frekuensi & Persentase \\
\hline $17-20$ & 100 & $50 \%$ \\
$21-25$ & 94 & $47 \%$ \\
$26-30$ & 4 & $2 \%$ \\
$>31$ & 1 & $1 \%$ \\
\hline
\end{tabular}




\begin{tabular}{ccc}
\hline Jumlah & $\mathbf{2 0 0}$ & $\mathbf{1 0 0 \%}$ \\
\hline Sumber: Data Primer (2017) & &
\end{tabular}

Berdasarkan tabel di atas, terlihat bahwa responden dengan segmen usia 17 tahun sampai 20 tahun lebih banyak, yaitu dengan persentase sebesar 50\% dan frekuensinya sebanyak 200 reponden. Diikuti dengan segmen usia 21 tahun sampai 25 tahun, yaitu dengan persentase sebesar $47 \%$ dan frekuensinya sebanyak 94 responden, kemudian usia 26 tahun sampai 30 tahun dengan persentase $2 \%$ dan frekuensinya sebanyak empat responden, serta di urutan terakhir responden usia lebih dari 31 tahun, yaitu dengan persentase $1 \%$ dan frekuensinya satu responden.

\section{Semester}

Tabel 2. Karakteristik Responden Berdasarkan Semester

\begin{tabular}{ccc}
\hline Smester & Frekuensi & Persentase \\
\hline Semester 2 & 90 & $45 \%$ \\
Semester 4 & 40 & $20 \%$ \\
Semester 6 & 36 & $18 \%$ \\
Semester 8 & 34 & $17 \%$ \\
Jumlah & $\mathbf{2 0 0}$ & $\mathbf{1 0 0 \%}$ \\
\hline
\end{tabular}

Sumber: Data Primer (2017)

Berdasarkan tabel di atas, bahwa responden semester dua lebih banyak dibanding responden semester lain, dengan persentase sebesar $45 \%$ dan frekuensinya sebanyak 90 responden, di posisi kedua adalah responden semester empat yaitu dengan persentase sebesar $20 \%$ dan frekuensinya sebanyak 40 responden. Ketiga adalah responden semester delapan dengan persentase $18 \%$ dan frekuensinya sebanyak 36 responden, kemudian yang terakhir adalah responden semester enam yaitu dengan persentase $17 \%$ dan frekuensinya sebanyak 34 responden.

\section{Fakultas}

Tabel 3. Karakteristik Responden Berdasarkan Fakultas

\begin{tabular}{ccc}
\hline Fakultas & Frekuensi & Persentase \\
\hline FIP & 10 & $5 \%$ \\
FBS & 14 & $7 \%$ \\
FIS & 8 & $4 \%$ \\
FMIPA & 0 & $0 \%$ \\
FE & 152 & $74 \%$ \\
FT & 20 & $10 \%$ \\
Jumlah & $\mathbf{2 0 0}$ & $\mathbf{1 0 0 \%}$ \\
\hline
\end{tabular}


Sumber: Data Primer (2017)

Dari tabel di atas, terlihat bahwa mayoritas responden dalam penelitian ini didominasi oleh responden FE sebanyak 152 responden dengan persentase sebesar $74 \%$. Kemudian responden FT sebanyak 20 responden dan persentase sebesar 10\%, responden FBS sebanyak 14 orang dengan persentase sebesar 7\%, kemudian responden FIP 10 responden dengan persentase 5\%. Serta responden FIS dengan persentase $4 \%$ sebanyak 8 orang, dan yang terakhir responden FMIPA 0\%. Keseluruhan responden berjumlah 200 responden.

\section{Responden yang menyaksikan iklan Garnier Light Complete versi Chelsea Islan, dalam satu bulan.}

Tabel 4. Karakteristik Responden Berdasarkan responden yang menyaksikan iklan Garnier Light Complete versi Chelsea Islan, dalam satu bulan.

\begin{tabular}{ccc}
\hline Menyaksikan & Frekuensi & Persentase \\
\hline$<3$ kali & 70 & $35 \%$ \\
$>4$ kali & 130 & $65 \%$ \\
Jumlah & $\mathbf{2 0 0}$ & $\mathbf{1 0 0 \%}$ \\
\hline
\end{tabular}

Sumber: Data Primer (2017)

Berdasarkan tabel di atas, terlihat bahwa responden yang menyaksikan iklan Garnier Light Complete versi Chelsea Islan dalam satu bulan lebih dari empat kali sebesar 65\%, dengan frekuensi 130 responden. Sedangkan responden yang menyaksikan iklan Garnier Light Complete versi Chelsea Islan dalam satu bulan kurang dari 3 kali sebesar 35\%, dengan frekuensi 70 responden. Maka dari itu jumlah responden yang menyaksikan iklan lebih dari empat kali lebih banyak dibandingkan dengan responden yang menyaksikan iklan kurang dari tiga kali.

\section{Hasil Pengujian Data}

\section{Uji Validitas}

Menurut Dantes (2012:86), validitas penelitian adalah kemampuan suatu penelitian untuk mengungkapkan secara tepat mengenai apa yang ingin diteliti, berikut adalah hasilnya: 
Jurnal Riset Manajemen Sains Indonesia (JRMSI) | Vol 9, No. 1, 2018

e-ISSN: $2301-8313$

http://doi.org/10.21009/JRMSI

Tabel 5. Uji Validitas Variabel Bintang Iklan $\left(X_{1}\right)$

\begin{tabular}{cccccc}
\hline $\begin{array}{c}\text { No } \\
\text { Item }\end{array}$ & $\mathbf{R}_{\text {hitung }}$ & $\mathbf{R}_{\text {tabel }}$ & Sig. & $\mathbf{N}$ & Keterangan \\
\hline 1. & 0,520 & 0,198 &, 000 & 200 & VALID \\
2. & 0,594 & 0,198 &, 000 & 200 & VALID \\
3. & 0,603 & 0,198 &, 000 & 200 & VALID \\
4. & 0,498 & 0,198 &, 000 & 200 & VALID \\
5. & 0,462 & 0,198 &, 000 & 200 & VALID \\
6. & 0,331 & 0,198 &, 000 & 200 & VALID \\
7. & 0,447 & 0,198 &, 000 & 200 & VALID \\
8. & 0,550 & 0,198 &, 000 & 200 & VALID \\
9. & 0,514 & 0,198 &, 000 & 200 & VALID \\
10. & 0,612 & 0,198 &, 000 & 200 & VALID \\
1. & 0,535 & 0,198 &, 000 & 200 & VALID \\
12. & 0,614 & 0,198 &, 000 & 200 & VALID \\
13. & 0,428 & 0,198 &, 000 & 200 & VALID \\
14. & 0,467 & 0,198 &, 000 & 200 & VALID \\
\hline
\end{tabular}

Sumber: Data diolah oleh peneliti (2017)

Pada hasil pengolahan uji validitas $\mathrm{X}_{1}$ di atas dinyatakan valid, karena masing-masing $r_{\text {hitung }}$ pada tiap-tiap pernyataan menyatakan angka lebih dari $r_{\text {tabel }}$ yaitu 0,198 .

Tabel 6. Uji Validitas Variabel Kepribadian Merek $\left(\mathrm{X}_{2}\right)$

\begin{tabular}{cccccc}
\hline $\begin{array}{c}\text { No } \\
\text { Item }\end{array}$ & $\mathbf{R}_{\text {hitung }}$ & $\mathbf{R}_{\text {tabel }}$ & Sig. & $\mathbf{N}$ & Keterangan \\
\hline 15. & 0,704 & 0,198 &, 000 & 200 & VALID \\
16. & 0,666 & 0,198 &, 000 & 200 & VALID \\
17. & 0,523 & 0,198 &, 000 & 200 & VALID \\
18. & 0,483 & 0,198 &, 000 & 200 & VALID \\
19. & 0,595 & 0,198 &, 000 & 200 & VALID \\
20. & 0,618 & 0,198 &, 000 & 200 & VALID \\
21. & 0,797 & 0,198 &, 000 & 200 & VALID \\
22. & 0,754 & 0,198 &, 000 & 200 & VALID \\
23. & 0,763 & 0,198 &, 000 & 200 & VALID \\
24. & 0,450 & 0,198 &, 000 & 200 & VALID \\
25. & 0,760 & 0,198 &, 000 & 200 & VALID \\
\hline
\end{tabular}

Sumber: Data diolah oleh peneliti (2017)

Pada hasil pengolahan uji validitas $\mathrm{X}_{2}$ di atas dinyatakan valid, karena masingmasing $\mathbf{r}_{\text {hitung }}$ pada tiap-tiap pernyataan menyatakan angka lebih dari $\mathbf{r}_{\text {tabel }}$ yaitu 0,198 . 
Tabel 7. Uji Validitas Variabel Karakteristik Produk $\left(\mathbf{X}_{3}\right)$

\begin{tabular}{cccccc}
\hline $\begin{array}{c}\text { No } \\
\text { Item }\end{array}$ & $\mathbf{R}_{\text {hitung }}$ & $\mathbf{R}_{\text {tabel }}$ & Sig. & N & Keterangan \\
\hline 26. & 0,724 & 0,198 &, 000 & 200 & VALID \\
27. & 0,654 & 0,198 &, 000 & 200 & VALID \\
28. & 0,466 & 0,198 &, 000 & 200 & VALID \\
29. & 0,745 & 0,198 &, 000 & 200 & VALID \\
30. & 0,774 & 0,198 &, 000 & 200 & VALID \\
31. & 0,683 & 0,198 &, 000 & 200 & VALID \\
32. & 0,599 & 0,198 &, 000 & 200 & VALID \\
33. & 0,480 & 0,198 &, 000 & 200 & VALID \\
\hline
\end{tabular}

Sumber: Data diolah oleh peneliti (2017)

Pada hasil pengolahan uji validitas $X_{3}$ di atas dinyatakan valid, karena masing-masing $r_{\text {hitung }}$ pada tiap-tiap pernyataan menyatakan angka lebih dari $r_{\text {tabel }}$ yaitu 0,198 .

Tabel 8. Uji Validitas Variabel Intensi Membeli (Y)

\begin{tabular}{cccccc}
\hline $\begin{array}{c}\text { No } \\
\text { Item }\end{array}$ & $\mathbf{R}_{\text {hitung }}$ & $\mathbf{R}_{\text {tabel }}$ & Sig. & N & Keterangan \\
\hline 34. & 0,595 & 0,198 &, 000 & 200 & VALID \\
35. & 0,567 & 0,198 &, 000 & 200 & VALID \\
36. & 0,805 & 0,198 &, 000 & 200 & VALID \\
37. & 0,788 & 0,198 &, 000 & 200 & VALID \\
\hline
\end{tabular}

Sumber: Data diolah oleh peneliti (2017)

Pada hasil pengolahan uji validitas $\mathrm{Y}$ di atas dinyatakan valid, karena masing-masing $\mathrm{r}_{\text {hitung }}$ pada tiap-tiap pernyataan menyatakan angka lebih dari $\mathrm{r}_{\text {tabel }}$ yaitu 0,198 .

\section{Uji Reliabilitas}

Menurut Sekaran (2010:161), keandalan reliabilitas menunjukkan sejauh mana data itu bebas kesalahan atau terpercaya dan oleh karena itu memastikan pengukuran yang konsisten sepanjang waktu dan di berbagai item dalam instrumen. Berikut adalah hasilnya:

Tabel 9. Uji Reliabilitas Variabel

\begin{tabular}{ccc}
\hline Cronbach' Alpha & $\begin{array}{c}\text { Reliability Statistics } \\
\text { Cronbach's Alpha Based } \\
\text { on Standardized Item }\end{array}$ & N of Items \\
\hline, 864 &, 861 & 11 \\
\hline Sumber: Data diolah oleh peneliti (2017)
\end{tabular}

Sumber: Data diolah oleh peneliti (2017) 
Suatu penelitian dikatakan memiliki tingkat reliabilitas memadai jika Cronbach's Alpha lebih besar atau sama dengan 0,600 (Sunjoyo et al, 2013:41). Dilihat dari perhitungan SPSS di atas maka hasil reliabilitas dinyatakan reliable karena Cronbach's Alpha sebesar 0,863 yang artinya lebih besar dari 0,600 yang menjadi patokan standar reliabilitas. Maka dari itu hasil dari uji reliabilitas tersebut menyatakan bahwa hasil pengukuran dapat dikatakan reliable.

\section{Uji Asumsi Klasik}

\section{Uji Normalitas}

Menurut Sunjoyoet al. (2013:59), uji normalitas bertujuan untuk mengetahui nilai residual terdistribusi normal atau tidak. uji normalitas bukan dilakukan pada masingmasing variabel tetapi pada nilai residualnya.Berikut adalah hasilnya:

Tabel 10. Uji Normalitas One-Sample Kolmogrof-Smirnov Test

\begin{tabular}{llr}
\hline & & Unstandardized Residual \\
\hline $\mathrm{N}$ & & 200 \\
Normal Parameters ${ }^{a, b}$ & Mean &, 0000000 \\
& Std. Deviation & 1,54180809 \\
Most Extreme Differences & Absolute &, 043 \\
& Positive &, 043 \\
& Negeative &,- 043 \\
Test Statistic & &, 043 \\
Asymp. Sig. (2-tailed) & &, $200^{\mathrm{c}, \mathrm{d}}$ \\
\hline
\end{tabular}

Sumber: Data diolah oleh peneliti (2017)

Berdasarkan uji normalitas yang dilakukan pada tabel di atas dengan pengolahan data menggunakan SPSS 22.0 dan uji Kolmogorov-Smirnov test,pada produk Garnier Light Complete dilihat bahwa nilai signifikan pada unstandardized residual dengan hasil 0,200. Hal ini menunjukan bahwa nilai signifikan lebih besar dari 0,05. Jadi dapat disimpulkan bahwa data penelitian ini berdistribusi normal.

\section{Uji Multikorelasi}

Menurut Sunjoyoet al. (2013:65), uji multikolinearitas adalah untuk melihat ada atau tidaknya korelasi yang tinggi antara variabel-variabel bebas dalam suatu model regresi linier berganda. Berikut adalah hasilnya: 
Tabel 11. Uji Multikorelasi

\begin{tabular}{lcc}
\hline & Collinearty Statistics & \\
Tolarence & & VIF \\
&, 693 & 1,443 \\
&, 365 & 2,740 \\
&, 386 & 2,589
\end{tabular}

Sumber: Data diolah oleh peneliti (2017).

Karena nilai VIF dari ketiga variabel ini lebih kecil dari 10, dan nilai tolerance lebih dari 0,1 maka dinyatakan tidak ada masalah multikorelasi pada ketiga variabel tersebut.

\section{Uji Heteroskedastisitas}

Menurut Sunjoyoet al. (2013:69), uji heteroskedastisitas adalah untuk melihat apakah terdapat ketidaksamaan varians dari residual satu ke pengamatan ke pengamatan yang lain. Berikut adalah hasilnya:

Tabel 12. Uji Heteroskedastisitas

\begin{tabular}{|c|c|c|c|c|c|}
\hline \multirow[t]{2}{*}{ Model } & \multicolumn{2}{|c|}{$\begin{array}{c}\text { Unstandardized } \\
\text { Coefficients }\end{array}$} & \multirow{2}{*}{$\begin{array}{c}\text { Standardized } \\
\text { Coefficients } \\
\text { Beta } \\
\end{array}$} & \multirow[t]{2}{*}{$\mathbf{T}$} & \multirow[t]{2}{*}{ Sig } \\
\hline & $\mathrm{B}$ & Std. Error & & & \\
\hline$($ Constant $)$ & 1,511 & ,878 & & 1,720 & ,087 \\
\hline $\mathrm{X}_{1}$ &,- 023 & ,018 &,- 110 & $-1,302$ & 195 \\
\hline $\mathrm{X}_{2}$ & 041 & ,022 & ,222 & 1,901 & 059 \\
\hline $\mathrm{X}_{3}$ &, 023 &, 030 &,- 086 &,- 756 & ,451 \\
\hline
\end{tabular}

Sumber: Data diolah oleh peneliti (2017)

Hasil dari uji heteroskedastisitas yang ditunjukan pada tabel di atas dapat diketahui bahwa nilai korelasi variabel bintang iklan $\left(\mathrm{X}_{1}\right)$ dengan unstandardized residual memiliki nilai signifikansi 0,195 >0,05. Nilai korelasi variabel kepribadian merek $\left(\mathrm{X}_{2}\right)$ dengan unstandardized residual memiliki nilai signifikansi 0,059>0,05.

\section{Pengujian Hipotesis}

Tabel 13. Coefficients

\begin{tabular}{|c|c|c|c|c|c|}
\hline \multirow[t]{2}{*}{ Model } & \multicolumn{2}{|c|}{$\begin{array}{c}\text { Unstandardized } \\
\text { Coefficients }\end{array}$} & \multirow{2}{*}{$\begin{array}{c}\text { Standardized } \\
\text { Coefficients } \\
\text { Beta }\end{array}$} & \multirow[t]{2}{*}{$\mathbf{T}$} & \multirow[t]{2}{*}{ Sig } \\
\hline & $\mathrm{B}$ & Std. Error & & & \\
\hline$($ Constant $)$ & 1,795 & 1,432 & & 1,254 & 211 \\
\hline $\mathrm{X}_{1}$ & ,066 & ,029 & , 149 & 2,287 & 023 \\
\hline $\mathrm{X}_{2}$ & ,005 & 035 &, 014 & 1,151 & 880 \\
\hline$X_{3}$ & ,305 &, 049 & -549 & 6,273 &, 000 \\
\hline
\end{tabular}

Sumber: Data diolah oleh peneliti (2017) 
Berdasarkan tabel hasil perhitungan uji t yang ada diperoleh hasil berikut:

1) $\mathrm{H}_{1}$ pengaruh bintang iklan $\left(\mathrm{X}_{1}\right)$ terhadap intensi membeli $(Y)$. Dari tabel diatas $t_{\text {hitung }}$ 2,287 lebih besar dari tabel 1,97. Signifikansi pada variabel bintang iklan sebesar 0,023 dan lebih rendah dari 0,05. Dapat disimpulkan bahwa H0 ditolak dan $\mathrm{H}_{1}$ diterima, karena $\mathrm{t}_{\text {hitung }}$ lebih besar atau lebih tinggi dari $\mathrm{t}_{\text {tabel}}$, dengan demikian terdapat pengaruh signifikan antara bintang iklan dengan intensi membeli.

2) $\mathrm{H}_{2}$ pengaruh kepribadian merek $\left(\mathrm{X}_{2}\right)$ terhadap intensi membeli (Y). Dari tabel diatas thitung 1,151 lebih besar dari tabel 1,97. Signifikansi pada variabel kepribadian merek sebesar 0,880 dan lebih besar dari 0,05. Dapat disimpulkan bahwa $\mathrm{H} 0$ diterima dan $\mathrm{H}_{2}$ ditolak, karena thitung lebih besar atau lebih tinggi dari $\mathrm{t}_{\text {tabel, }}$ dengan demikian tidak terdapat pengaruh yang signifikan antara kepribadian merek dengan intensi membeli.

3) $\mathrm{H}_{3}$ pengaruh karakteristik produk $\left(\mathrm{X}_{3}\right)$ terhadap intensi membeli $(Y)$. Dari tabel diatas $t_{\text {hitung }}$ 6,273 lebih besar dari $\mathrm{t}_{\text {tabel }}$ 1,97. Dapat disimpulkan bahwa H0 ditolak dan $\mathrm{H}_{3}$ diterima, karena $t_{\text {hitung }}$ lebih besar atau lebih tinggi dari $\mathrm{t}_{\text {tabel }}$, dengan demikian terdapat pengaruh yang signifikan antara karakteristik produk dengan intensi membeli.

\section{KESIMPULAN DAN SARAN}

\section{Kesimpulan}

Berdasarkan hasil penelitian dan pembahasan, maka dapat ditarik kesimpulan sebagai berikut:

1. Terdapat pengaruh bintang iklan terhadap intensi membeli Garnier Light Complete. Hal ini dapat dibuktikan dari hasil analisis regresi yang menunjukkan tingkat signifikan sebesar 0,023 yang berada di bawah batas maksimum toleransi kesalahan, yaitu 0,005 . Dengan demikian $\mathrm{H}_{1}$ didukung oleh data dan hasil ini mendukung hipotesis awal peneliti yang diajukan dalam penelitian.

2. Dari hasil analisis yang telah dilakukan oleh peneliti, diketahui bahwa tidak terdapat pengaruh kepribadian merek terhadap intensi membeli Garnier Light Complete. Hal ini dapat dibuktikan dari hasil analisis regresi yang menunjukkan tingkat signifikan 
sebesar 0,880 yang berada di atas batas maksimum toleransi kesalahan, yaitu 0,005. Dengan demikian $\mathrm{H}_{2}$ tidak didukung oleh data dan hasil ini tidak mendukung hipotesis awal peneliti yang diajukan dalam penelitian.

3. Karakteristik produk berpengaruh secara signifikan terhadap intensi membeli Garnier Light Complete. Hal ini dapat dibuktikan dari hasil analisis regresi yang menunjukkan tingkat signifikan sebesar 0,000 yang berada di bawah batas maksimum toleransi kesalahan, yaitu 0,005. Dengan demikian $\mathrm{H}_{3}$ didukung oleh data dan hasil ini mendukung hipotesis awal peneliti yang diajukan dalam penelitian.

\section{Saran}

Berdasarkan hasil penelitian dan pembahasan, maka dapat ditarik kesimpulan sebagai berikut:

Bagi Perusahaan:

1. Bintang iklan Garnier Light Complete: karena Chelsea Islan dalam membintangi iklan Garnier Light Complete terlihat meyakinkan, menarik, dan terkenal dikalangan anak muda, maka dari itu dalam penelitian ini penggunaan Chelsea Islan sebagai bintang iklan Garnier Light Complete berpengaruh signifikan terhadap intensi membeli. Dari hasil penelitian ini, penggunaan kalimat yang diucapkan oleh Chelsea Islan "jadi putih cerah” yang melekat pada produk Garnier Light Complete saat ini, ternyata mewakili produk dan diterima oleh pemikiran konsumen. Jadi, berkat bintang iklan yaitu Chelsea Islan, menjadikan Garnier dapat masuk peringkat 2 TOP BRAND Indonesia dari tahun 2015 sampai dengan tahun 2017. Saran dari peneliti, diharapkan Chelsea Islan tetap dapat mempertahankan kualitas bekerjanya dalam membintangi iklan Garnier Light Complete agar para konsumen tetap tertarik pada Garnier Light Complete.

2. Kepribadian merek Garnier Light Complete: dapat dijadikan masukan bagi Garnier Indonesia, bahwa penggunaan kepribadian merek dalam produk Garnier Light Complete tidak berpengaruh signifikan terhadap intensi membeli. Maka, perusahaan harus lebih memperhatikan pembentukan kepribadian merek yang jelas dan kuat dalam produk, karena hal tersebut akan 
dijadikan bahan pertimbangan konsumen, apakah calon konsumen akan melakukan pembelian produk yang sesuai dengan dirinya atau calon konsumen tidak akan melakukan pembelian produk karena produknya tidak sesuai dengan dirinya.

3. Karakteristik produk Garnier Light Complete: penelitian ini dapat dijadikan masukan bagi Garnier Indonesia, bahwa karakteristik produk Garnier Light Complete berpengaruh secara signifikan terhadap intensi membeli. Dari karakteristik produk yang ditawarkan Garnier Light Complete dapat mempengaruhi persepsi positif konsumen, dan mendorong konsumen untuk melakukan pembelian dan menggunakan produk Garnier Light Complete. Maka perusahaan harus tetap mempertahankan dan mengembangkan karakteristik yang unik dan berbeda dari produk lainnya dan terus melakukan inovasi produk sesuai dengan perkembangan zaman.

Bagi Peneliti Selanjutnya

Bagi peneliti selanjutnya dapat mengembangkan penelitian ini dengan meneliti faktor lain yang dapat mempengaruhi intensi membeli, misalnya asosiasi merek. Peneliti selanjutnya juga dapat menggunakan metode lain dalam meneliti intensi membeli, misalnya melalui wawancara.

\section{DAFTAR PUSTAKA}

Aaker, D. (2010). Manajemen Ekuitas Merek. Jakarta: Mitra Utama.

Anoraga, P. (2010). Manajemen Bisnis. Semarang: PT. Rineka Cipta.

Assael, H. (2011). Consumer Behavior 6th Edition. New York: Thomson-Learning.

Dantes, N. (2012). Metode Penelitian. Yogyakarta: Andi.

Hartini, S. (2012). Peran Inovasi: Pengembangan Kualitas Produk dan Kinerja Bisnis. Jurnal Manajemen dan Kewirausahaan, Vol.14, No. 1, Maret 2012: Hal. 6390.

Kotler, P. (2012). Manajemen Pemasaran Jilid 2. Jakarta: PT. Indeks Kelompok Gramedia.

Kotler, P. dan Armstrong, Gary. (2012). The Principle of Marketing Management. USA: Prentice Hall. 
Kotler, P. dan Armstrong, Gary. (2010). Prinsip-Prinsip Pemasaran Edisi 12. Jilid 1 Jakarta: Erlangga.

Kotler, P. dan Armstrong, Gary. (2012). Principles of Marketing Edisi 1. United States of America: Pearson.

Kotler, P. dan Keller, Kevin Lane. (2012). Marketing Management. Pearson Education Inc.

Kotler, P. dan Keller, Kevin Lane. (2012). Marketing Management 14th Edition. New Jersey: Pearson Education, Inc.

Nurani, E. S. dan Haryanto, Jony O. (2010). Pengaruh Celebrity Endorser, Brand Association, Brand Personality Dan Product Characteristics Dalam Menciptakan Intensi Pembelian (Studi Pada Iklan Kuku Bima Ener-G Rosa Versi Chris John). Journal of Business Strategy and Execution 2 (2). pp. 104125 .

Sekaran, U. dan Bougie, Roger. (2010). Research Methods for Business. Chichester, John Wiley \& Sons Ltd.

Shimp, T. A. (2010). Promotion Event. South Carolina: The Dryden Press.

Shimp, T. A. (2010). Periklanan dan Promosi. Erlangga, Jakarta.

Shimp, T.A. (2010). Advertising, Promotion, and Other Aspects of Integrated Marketing Communication, 8th Edition. South-Western, CengageLearning.

Solomon, M.R. (2010). Consumer Behavior Buying, Havingg and Being. (7thed.).New Jersey: Person Prentice Hall.

Sumarwan, U. (2012). Perilaku Konsumen: Teori dan Penerapannya dalam Pemasaran. Bogor: Ghalia Indonesia.

Sunjoyo., Setiawan Roni., Carolina Verani., Magdalena Nonie. dan Kurniawan Albert. (2013) .Aplikasi SPSS Untuk Smart Riset. Bandung, Alfabeta.

http://www.loreal.co.id diakses pada tanggal 1 Juli 2017. 